\title{
$P E-119-16$
}

\author{
TERRITORY OF ALASKA \\ DEPARTKENT OF $U I N E S$ \\ B. D. Stevrart \\ Comisaloner of Mines \\ - 0 -
}

\section{PRELIYINARY REPORT \\ OF \\ LUCKY BOY GROUP OF CLAINS, \\ DORA BAY, CHOLMONDELEY SOUND \\ PRINCE OF WALES ISLAND, ALASKA.}

May 11, 1939

By

J. C. ROETM

NOTE: The Territorlal Department of Mines will welcome reprinting the materlal that apnears in this Renort provided the followlng footnote acknovledgrent is ueed - "Reproduced from Territorlel Department of MInes Report oy J. C. Roehm, dated Nay 11, 1939". 


\author{
FRELIYINARY REPORT OF LUCKY BCY GEOUP \\ OF CLAIKS, DORA BAY, CHOLYONDELYY \\ SOUND, FRINCE OF WALES ISLAND. \\ ALASKA \\ ki..Y 11, 1939
}

Location ars Acoessibility:

The Lucky Boy group of lode clalms is located at the south end of Dora Lake, one ano. three-fourth miles from salt vater at a nolnt at the heed of Dora Bsy. The latter is a small bey three miles in length on the south side of Cholmondeley Sound on the east side of Prince of Viles Islanc. The claim group le reached vif tra1l from the hesc of Dora Bay, one-fourt: mile in leneti to Dora leke, end thence by bost to the south enc or nesi. Anowizer rolite is vis trall from tire nes. of the ilorts. Arn of Molre Sound via the north shore of linerel Lake. (Note Plate No. 1). The elevations vie trail to the cleim exoup are less then 100 feet.

\title{
Ormers:
}

This group of elght clatms; nemely, Lucky Boy Nos. I to

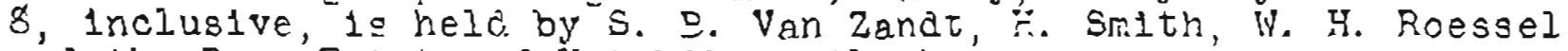
and the Ryus Eetate of Ketchikan, Alsska.

History:

The discoverer of the showings on this groun of cleins is not know. The first known writte: eccount of this doscovery is given in $U, S$. $\approx$. S. Professional Faper No. I, "Preliminary Report or tire Ketchikan Minine District, Aleskall by A. H. Brooks: p. 79. It ves thes knowr. as the Frisco cleim. Brooke mexely refere to this discovery as o. minerelized zone feet wide and carryine zinc blende, lron end copper pyrite, and selene. The date of diecovery of the present West Lake vein or Fr1soo group 1s given in U. S. C. S. Bullet1r 347, "Ketchiken end Wrangell Mining D1stricts" by F. E. and C. "irimhi, po. 171-172, e.8 1899. It was relocated in 1903 e.s the Oregon and Icibo prospects, of which this report gives a short descrintion. The Lady of the Lake Vein was enparently discovered prior to tilis letter repori. as It is cescribed uneren the Ledy of the Le're claime. Later the two cleim grouns were located es the Complex srour ano are referred

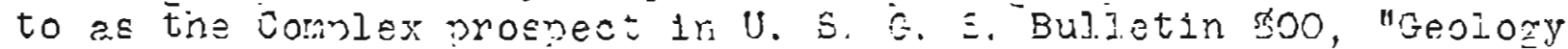
anc Kinerel Denostis of Southesstern Alsexa" by s. F. Buddincton

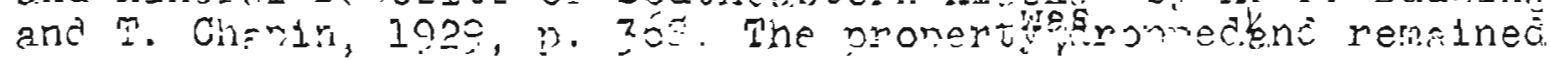
onen for severs. vens unc1z steked by joe present orners in 1937. 


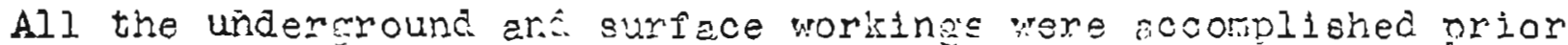
to the lest stakine, as noted on date of examination. An ettempt to mine and bill the ore of the liest lake vein hod been wade several years ago $8 \varepsilon$ the mill 18 of an old type sno obsolete at the present time. The history of this activity is not know.

Geologyr ono Sinovinos:

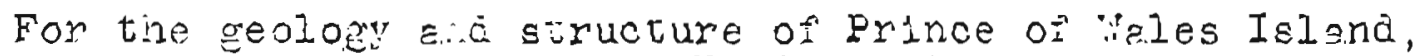
the above-mentioned renonts of the $t . S . G . S$. pre asain referred to. The formetion noted on this groun of cleing consiats or a folded greenstone schist. This achist aneare merosconlcally to originally have been a volcenic extrusive rock or tufi. This Pormation hes been covered with 11mestone which rested unconformably on the former. Subseouent erosion has removed tine limestone, rith the exceotion of occesionel reranants, the latter existing as fliled flesures, brecciatea zones, anâ heró crvstalline masses. The schistosity of the creenstone sorists strikes ?. $10^{\circ}$ to $20^{\circ} \mathrm{W}$. and the diy veries due to foldin fror $50^{\circ}$ to $70^{\circ}$ sir.

Three snown veins exist on tine property anc naned in order of economic 1mportonce are the Hest Laks vein, located on tine Lucky Boy No. 4 clalm, the Lady of the Lake and tine linnetonks veins on the Lucky Boy No. I claim.

The weet Loke vein, originpliy known os the oregon ond Ideho prospects of the Prisco group, is exposed by sunface cuts for e alstance of 400 peet. This vein cuts the schistosity of the schists ano strikes 1:. $20^{\circ} \mathrm{E}$. and has an average dip of $50^{\circ} \mathrm{W}$. The minerglized section of this vein. which consists of a linestone filled fissure, veries fron e few inches to five feet, with the entire width including berren limestone varying un to eight feet. The vein is irreoular as to size and mineral content, and in places has been subject to s slight post mineral movement.

The hacy of the Lake veln is a shesred mineralized zone in greengtone schist vith sinell ouartz and celcite veinlete inclosed and conformeible to the strike and dip of the schistosity. This zone is exposea by cuts for nearly 200 feet, end one large cut exposes the outcrop on the din for 30 feet in extent. The actual width could not be cocuratelir cetermined, but eonears to vary betreen 10 to 12 feet. This zone contains en abundence of lime minerals, but lacks the blocks of limestone tinet ere found in the West lake ve1n.

The Minnetonko vein lies 150 feet directly north of the Lady of the Lake vein anc consists os an iryegular oanded vein inclosed in $e$ eheor zone developed by more intense folding. This vein veries ir. viath from fev incines to four reet in the crests of tine osen folce. The vela, fron 1 te locetion ari cenarel strice. sinows a arester etilke to tine nortinest tion tine lake of the loke

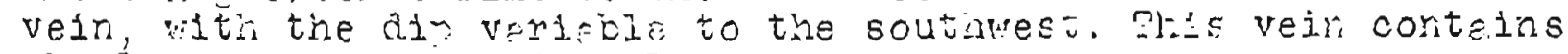

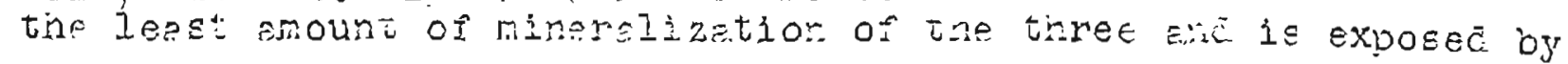


cuts only for 200 feet. Shell ouartz cross veins were observec intersecting the mein vein, ena ere filled tensior frectures ceused by the fordin ene novenent.

Develooment:

The velns heve Deer aeveloned by two adi tunnels, one shaft, enc one short vinze. Aalt No. I (note Plate No. 2) has ?

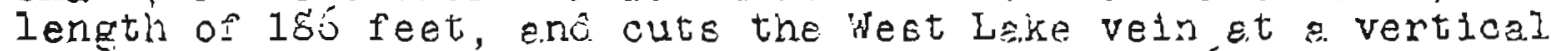
distence of 75 feet beloy 1is outcrop. A orift $6=$ feet north and 46 ieet south exnoses the ve1n for distance of 111 feet. The ve1n averages from 3 to 3 ieet in ridth, anc nas been stoped a few feet un in both arifts near the latter's enas. The vein 16 narrowerer than on the suriace, conteing a legeer amount of Iimestone and mineralization, and has a more orecolated nature. At the end of the crosscut adit a siont winze ises beer suak, which is now Pilled. A chernel sanole was taken et the face of each drift.

Adis tuniel ito. 2 was driven et sn eleveiton of 220 îte and g5 feet belo" the Locy of the lake vein, directly belo: tine large outcron. This crosscut tunnel has besx a lenmtin of 66 feet snd cuts s vein that rences from 4 to jeet ir with at a point 47 feet from the nortal. There is some doubu as to wizether or not thls crosscut hes cut the entire veir zone. A chennel sample vis

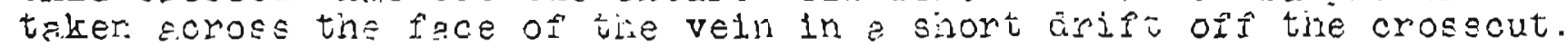

The linnetonire veln $1 \mathrm{~s}$ exposed by opencuts ano due to the poor exposures in the olc cuta, no sanples were taken.

One shaft wes sunic on the Weat Lake velr as sirom on Plete No. 3, but is now p1liea.

世1nergizetion:

Tho hesviest minerplizotion is fount in tip sumface cute of tine liest leke velu. Here tine minereifistion is a replecement of the limestone ano. Ir spots is maseive, consiatine mainly of sphalerite. The Lady of the lake vein contalns a seater pyrite mineralizetion with some galena, chalcopyrite end sphalerite. The Minnetonle veir contained mostly pysite with smell amounte of galena, chalconvrite anc sphalerite. Associztes vith these metals, lou values of cold ans sllver rere noted by assay. Traces of cadmin were reported founc asoocistec rith tise sonalerite in the vest Lake vein.

The Fangue finerals congist mainly or ouartz, calcite, various eltered lime ainerals anc conslcerable limonite, heretive and magnetile - tile la vier two meiniy ir the iest Lake veir. pieces or elterec minersilzeo ereeretone schis: is cono: in tise velns. 
Due to the fbumance of oxides, lime silicates anc minersis, end the eenerel character of the type of ore, this denosit is classifiec as low temoersture and of shallo: centi.

SambIing snc Assays:

Pleter Nas. 2 and 3 show the locetions, widthe and reeults of all samples taken. They also contaln the semples teisen by $\mathrm{E}$. $G$. Wilcox in June, 1937. These eamples do not represent a detalled samplins of thege showings, but the a glve representative regults rhich rould incicate the results of such a saming. The gold and silver content is low. Both lead end conver vilues are low. High zinc results were obtsined on the iest lake vein, in sections where coneldereble snhalerite was noted, however, this 1 s not cinaracteristic

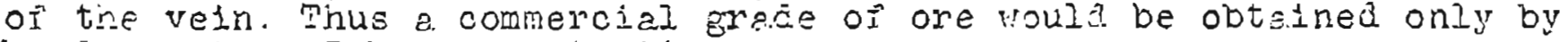
hene sorting or by concentration.

Timber onc ifoter Foner:

Timber, meinly spruce and inemlock, le abundant on the property and the surroundine section.

Small nydro-electric nower could be ceveloned within 8 few miles. However, the lekes shown on Plate No. 1 ane of too loll an elevetion to develon power. The power used ir. the old mill below the Hest lake velr consistec of $a$ stepr boller anc ensine. A rod mili, tasles, anc crusher are stili intect in the buliding, but all $\mathrm{m}=$ chinery is obsolete, except possibly tise crusher. 